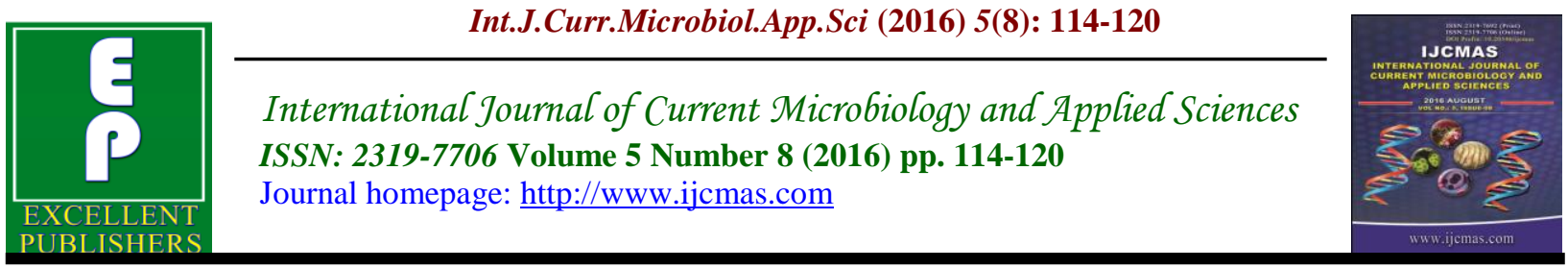

Original Research Article

http://dx.doi.org/10.20546/ijcmas.2016.508.014

\title{
Morphometric Studies on Duttaphrynus melanostictus (Schneider, 1799) Anura: Bufonidae from Central India, Bhopal (MP) with Special Reference to their Mortality by Roads
}

\author{
Amit Kotwal $^{1 *}$, Rajni Raina ${ }^{2}$ and Ashwani Wanganeo ${ }^{1}$ \\ ${ }^{1}$ Department of Environmental Sciences and Limnology Barkatullah University, \\ Bhopal (MP), India \\ ${ }^{2}$ Department of Zoology, Govt. Science and Commerce College (Benazir), Bhopal (MP) India \\ *Corresponding author
}

\section{A B S T R A C T}

Keywords

Duttaphrynus melanostictus, Amphibians,

Road kill, Morphological characteristics, Bhopal.

Article Info

Accepted:

08 July 2016

Available Online:

10 August 2016
Based on 60 days of field visits (June 2014 to December 2014) a total of 281 specimens of Indian common toad (Duttaphrynus melanostictus) were spotted. Statistical analysis with traditional morphometry was performed to analyze the intra population variation in Duttaphrynus melanostictus (Anura: Bufonidae) from Bhopal, Madhya Pradesh. In this paper we have presented morphological variation in 20 individuals of Duttaphrynus melanostictus. Regression analysis was performed for three morphometric variables viz., Head width(HW) with Snout vent length(SVL) and Hind limb length (HLL) with Snout vent length (SVL) and fitted regression equation $\mathrm{y}=0.2995 \mathrm{x}-0.0103\left(\mathrm{R}^{2}=1\right)$ and $\mathrm{y}=1.0247 \mathrm{x}-0.0381\left(\mathrm{R}^{2}=1\right)$ respectively were obtained for the species. Besides this during current work we have observed various anthropogenic pressures but road kill is seen one of the main factor causing amphibian mortality.

\section{Introduction}

Amphibians are the ectotherms which have moist skin and are entirely reliant on environmental heat to maintain their body functions. India harbours 342 species of amphibians which includes 306 anuran species, 35 species of Gymnophiona and 1 salamander species (Dinesh et al., 2013). In Madhya Pradesh Chandra et al., (2005) had studied and documented 18 species of amphibians. Among them toads are quite different from frogs. Toads generally have shorter legs, warty dry skin and have paratoid glands behind the eyes. Bufonidae is a large and geographically widespread taxon of neobatrachian frogs (Duellman and Trueb, 1986).

The family Bufonide have 597 species and 51 genera, while the genus Duttaphrynus has 29 species (http://www.amphibia web.org/ about/index.html). More than half of the species within the family Bufonidae are contained within the genus Bufo. Duttaphrynus melanostictus commonly called as Asian common toad, Black spectacled toad which belongs to family 
Bufonide and genus Duttaphrynus. This species is found in almost all types of biotopes found in the country and occurs from sea level up to $2000 \mathrm{~m}$ in the hills (Daniel, 2013).

\section{Study Area}

The present study was undertaken in and around Bhopal city, Madhya Pradesh. Bhopal is the capital of Madhya Pradesh and also known as city of lakes. The geographical location lies within $23^{\circ} 16 \mathrm{~N}$ and $77^{\circ} 36 \mathrm{E}$. It has an average elevation of 500 meters (Fig.1). Bhopal experiences a moderate climate though summers are hot and the temperature may touch $45^{\circ} \mathrm{C}$. During winter the temperature is around $10^{\circ} \mathrm{C}$.

\section{Materials and Methods}

The present study was conducted from June 2014 to December 2014 to see the abundance, morphological parameters of Duttaphrynus melanostictus and the impact of vehicular traffic. The survey was conducted visually near human dwellings, playing parks, and micro-habitats like on the floor rocks under the soil, around roads individuals of Duttaphrynus melanostictus were collected from different selected sites. Live specimens $(\mathrm{N}=20)$ were collected and twenty measurement characters (Chowdhary et al., 2014) using Vernier caliper was recorded. Morphometric measurements of the samples $(\mathrm{N}=20)$ collected during the survey were taken in the field conditions and animals were released after recording the observations. Precautions were taken that no stress on the animals was applied during the course of the measurements.

To enumerate the direct impact of roads on Duttaphrynus melanostictus the number of road kills that occurred on highways and link roads were counted. These roads were surveyed systematically between 5:30 pm to
10:00 pm once a week from June 2014 to December 2014.

\section{Result and Discussion}

For the current study we have studied graphic statistics data along with the correlation analysis are tabulated consecutively (Table 1 and 2). Regression plots for morphometric parameters viz., SVL and HW; SVL and HLL of Duttaphrynus melanostictus with fixed regression equation are also depicted (Fig. $4 \mathrm{a}$ and $\mathrm{b})$. Average SVL of the sample measured was found to be $9.20 \mathrm{~cm}$. A considerable positive correlation was obtained between the 20 important morphometric parameters considered at the $1 \%$ level of significance (Fig.3). Regression analysis was performed for three morphometric variables viz., Head width (HW) with Snout vent length(SVL) and Hind limb length (HLL) with Snout vent length(SVL) and fitted regression equation $y$ $=0.2995 \mathrm{x}-0.0103\left(\mathrm{R}^{2}=1\right)$ and $\mathrm{y}=1.0247 \mathrm{x}$ $-0.0381\left(R^{2}=1\right)$ respectively were obtained for the species.

\section{Morphological Characteristics}

The specimens were larger in size, tympanum was distinct, circular in shape $3 / 4$ the diameter of eye. Snout is little obtuse, pupil rounded, tongue oval. Dorsally the skin is deeply tuberculated and has a lot of black spine-tipped warts all over the body (Fig.2). Paratoid glands and cranial ridges were prominent. In adult's tips of toes, fingers, metatarsal tubercles and tubercles on the palm of hand have black cornifications while in juveniles such black cornifications are not developed until they attain size of $25-35 \mathrm{~mm}$.On ventral side adults are uniform white while juveniles have white as well as black markings. Heels don't meet when kept at right angle to the body. 
Table.1 Morphological parameters used in the study

\begin{tabular}{ll}
\hline SVL & Snout-vent length \\
\hline HL & Head length(from back of mandible to tip of snout) \\
HW & Head width(left side back of mandible to right side back of mandible) \\
STL & Snout-tympanum length(tip of snout to front of tympanum) \\
MSL & Mouth angle-snout length(tip of snout to end of mouth opening) \\
NS & Nostril-snout length(distance from nostril to tip of snout) \\
NTL & Nostril tympanum length(distance between nostril and front of tympanum) \\
EN & Distance from front of eye to nostril \\
TEL & Tympanum eye length(distance between end of eye to front of tympanum) \\
TD & Tympanum diameter(maximum diameter) \\
IN & Internarial distance(distance between 2 nostrils) \\
EL & Eye length(greatest diameter of the eye including upper eye lids) \\
IOD & Interorbital distance \\
FAL & Fore arm length(from elbow to base of outer palmer tubercle) \\
HLL & Hind limb length \\
THIGHL & Thigh length \\
TL & Tibia length \\
Three FL & Third finger length \\
One FL & First finger length \\
Fourth FL & Fourth finger length \\
\hline
\end{tabular}

Table.2 Descriptive statistics of morphometric parameters of Duttaphrynus melanostictus $(\mathrm{N}=20)$ from Bhopal city, Madhya Pradesh, India.

\begin{tabular}{lcccc}
\hline Parameters & Maximum & Minimum & Mean & Deviation \\
\hline SVL & 13.1 & 5 & 9.2 & 2.304 \\
HL & 3 & 1 & 2.35 & 0.596 \\
HW & 3.9 & 1.5 & 2.75 & 0.691 \\
STL & 2.4 & 0.8 & 1.7 & 0.438 \\
MSL & 3.1 & 1.2 & 2.2 & 0.565 \\
NS & 0.5 & 0.1 & 0.27 & 0.101 \\
NTL & 2.1 & 0.8 & 1.5 & 0.389 \\
EN & 1 & 0.4 & 0.7 & 0.158 \\
TEL & 0.15 & 0.06 & 0.10 & 0.027 \\
TD & 0.8 & 0.3 & 0.55 & 0.149 \\
IN & 0.8 & 0.3 & 0.55 & 0.156 \\
EL & 1.7 & 0.6 & 1.04 & 0.316 \\
IOD & 1.5 & 0.6 & 1.05 & 0.274 \\
FAL & 7.6 & 3 & 5.3 & 1.33 \\
HLL & 13.5 & 5.2 & 9.45 & 2.36 \\
THIGHL & 3 & 1.2 & 2.1 & 0.511 \\
TL & 4 & 1.6 & 2.9 & 0.71 \\
3FL & 0.8 & 0.3 & 0.54 & 0.150 \\
1FL & 0.8 & 0.3 & 0.55 & 0.150 \\
4TL & 3.7 & 1 & 1.85 & 0.649 \\
\hline
\end{tabular}


Fig.1 Showing the satellite imagery of the current study area (Source: Google earth)

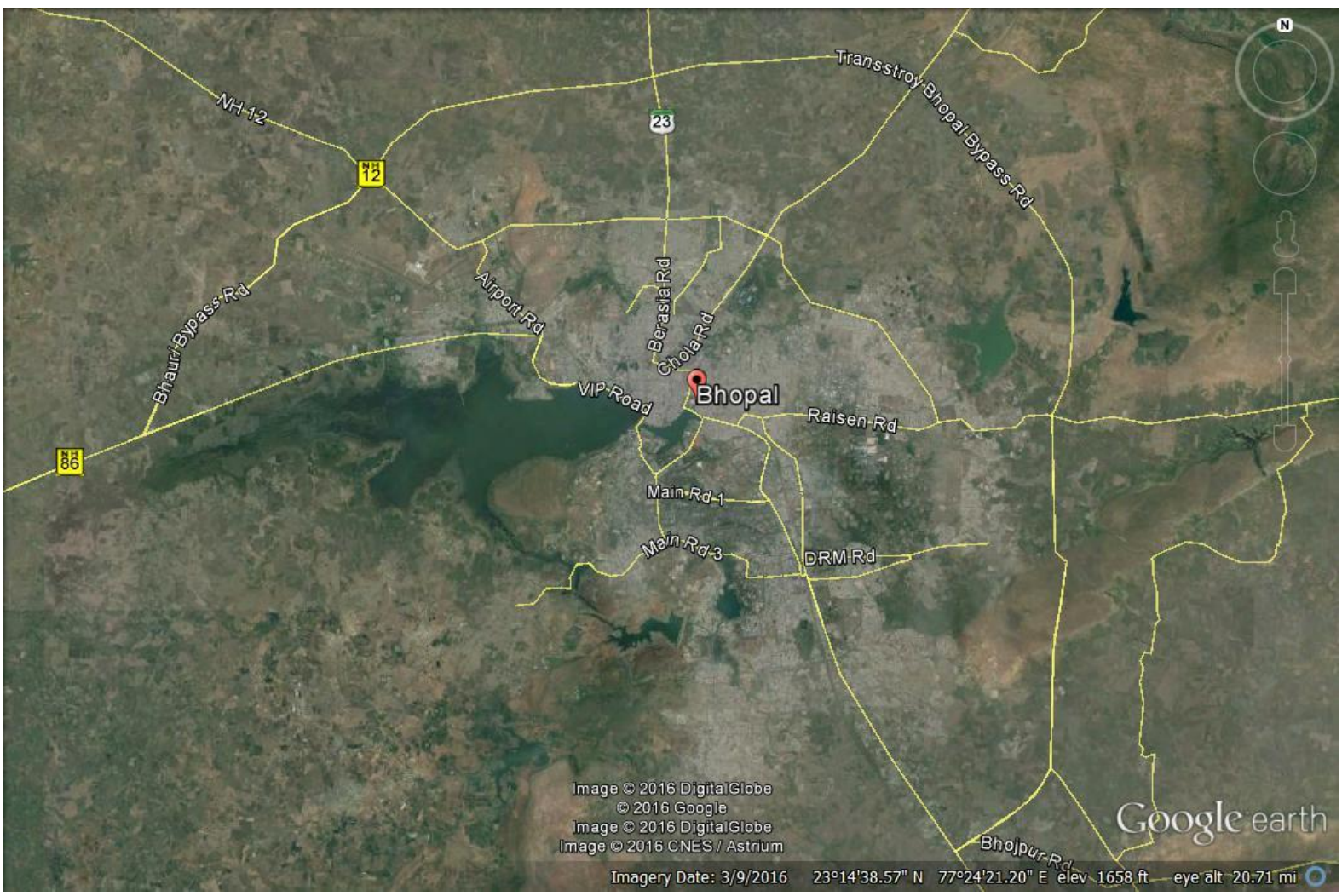

Fig.2 A. Dorsal view. B. Showing Road Kill. C. Lateral view. D. Ventral view of Duttaphrynus melanostictus

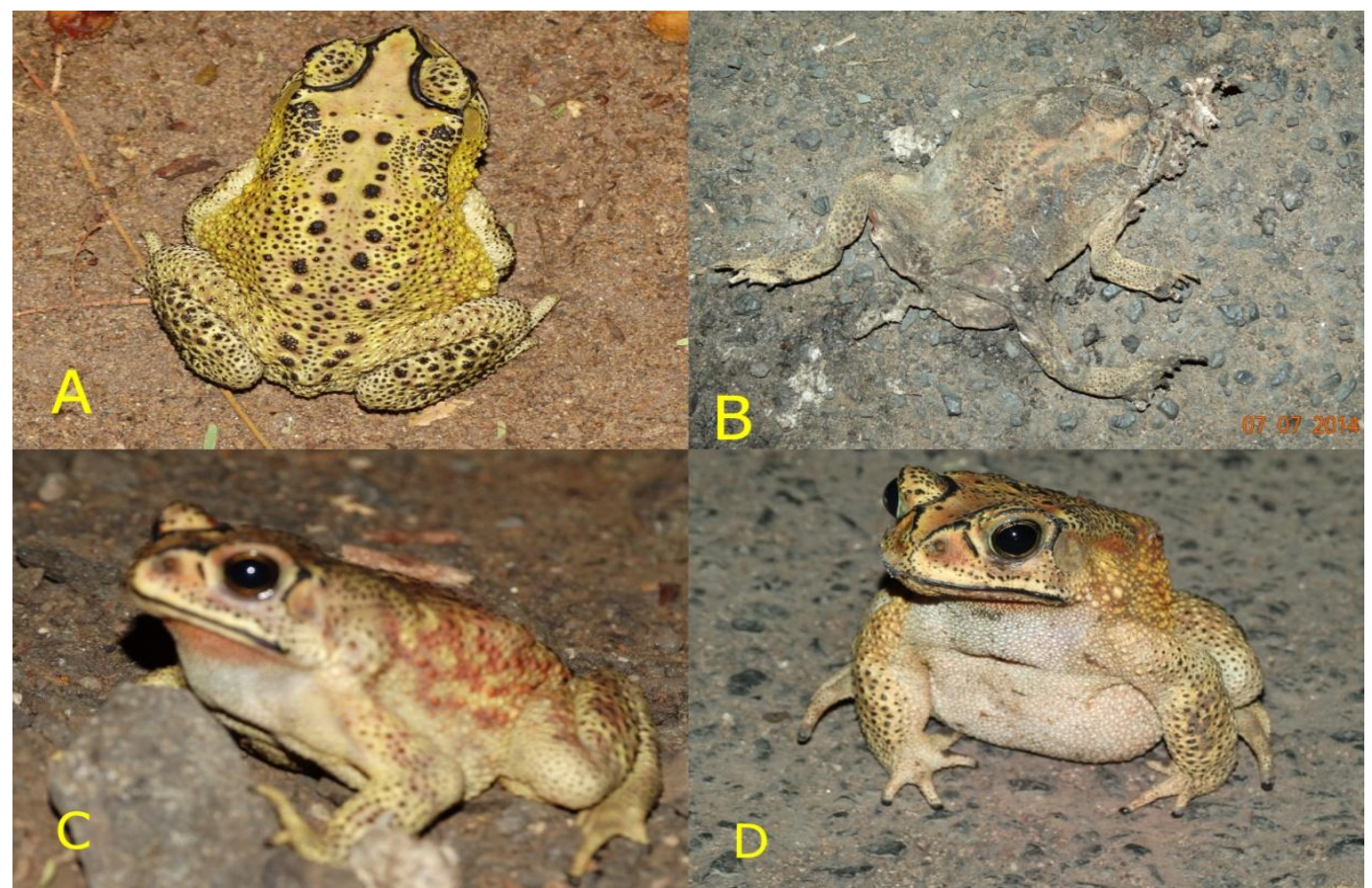


Fig.3 Correlation coefficient (r) values for important morphometric parameters of Duttaphrynus melanostictus $(\mathrm{N}=20)$ from Bhopal region, Madhya Pradesh, India

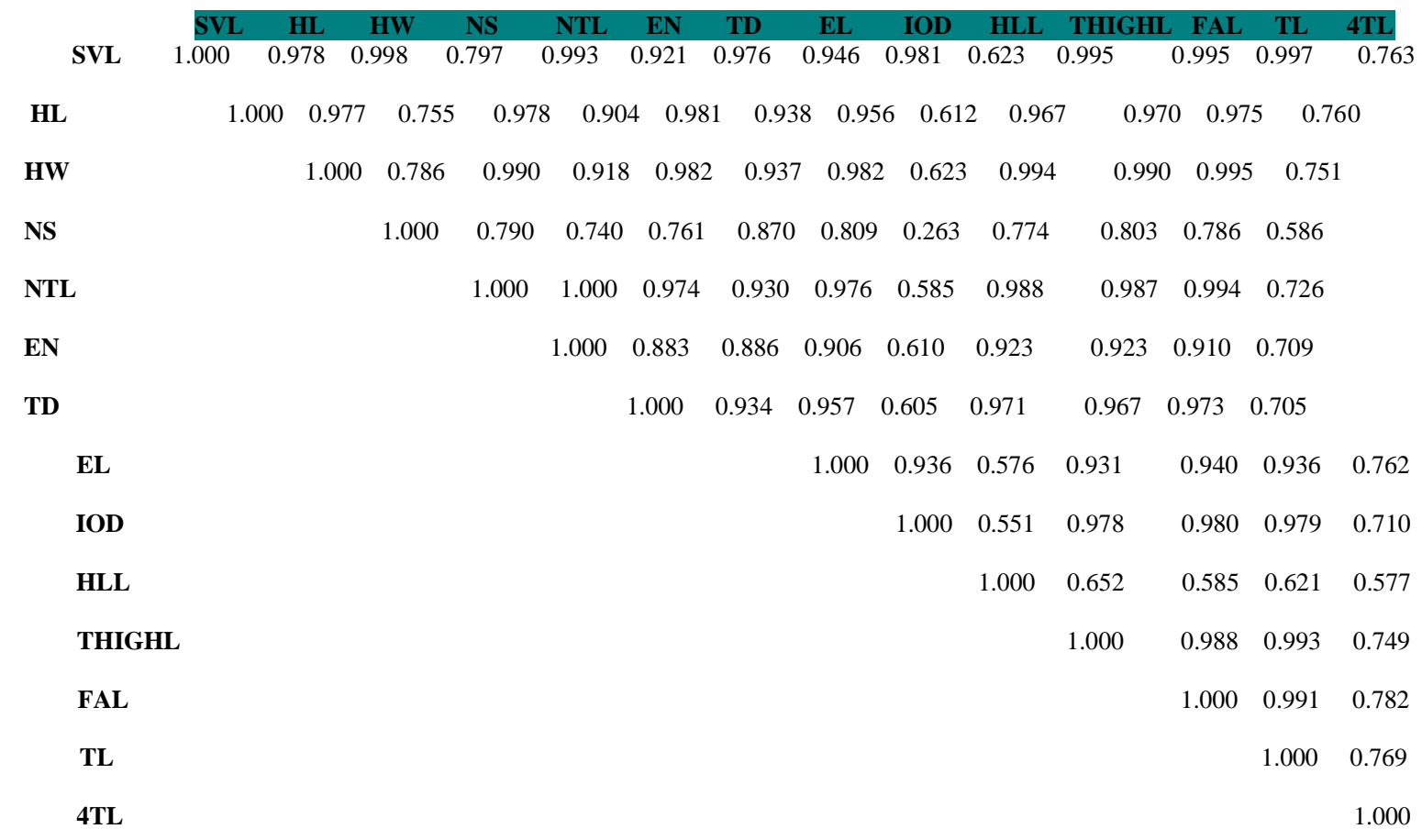

Fig.4 (a \& b) Regression analysis plots for morphometric parameters of Duttaphrynus melanostictus with fitted regression equation

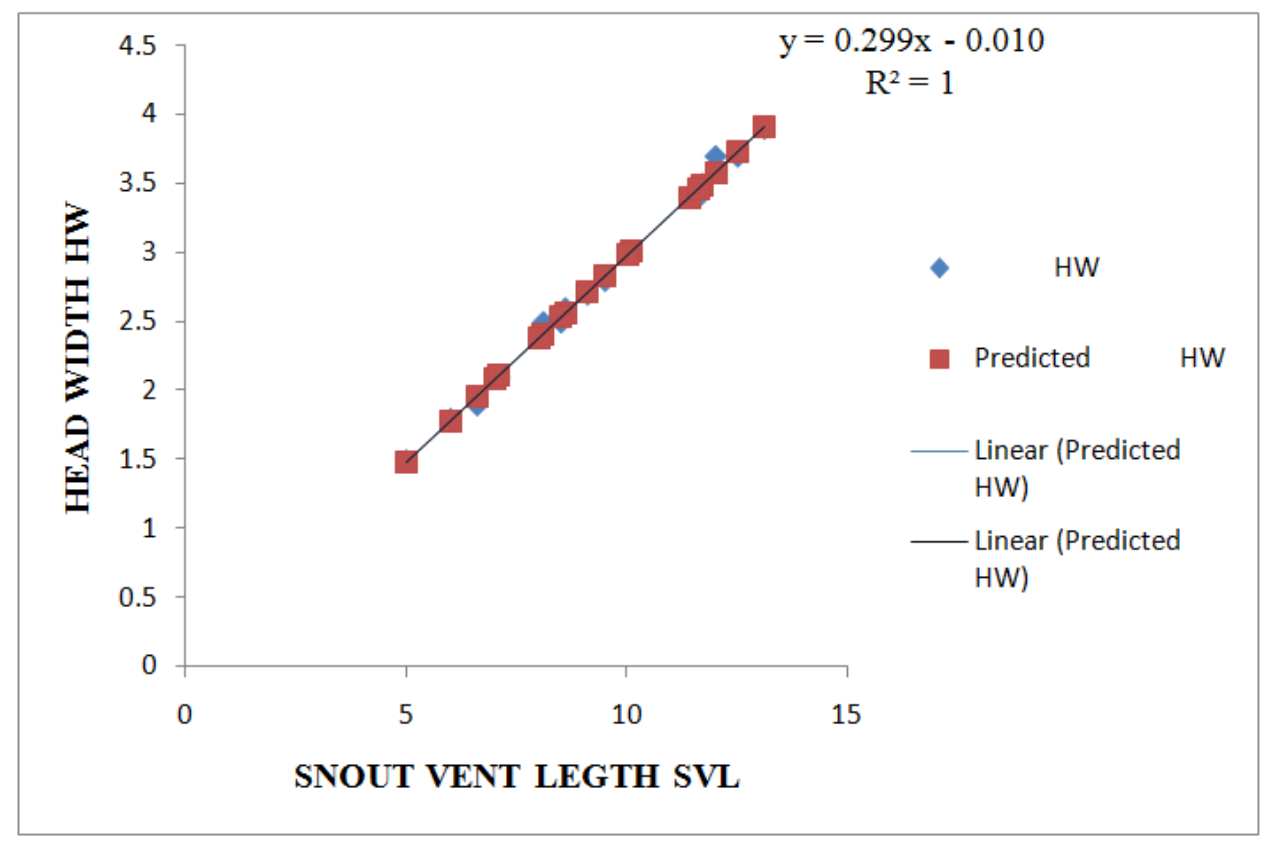

Fig.4a 


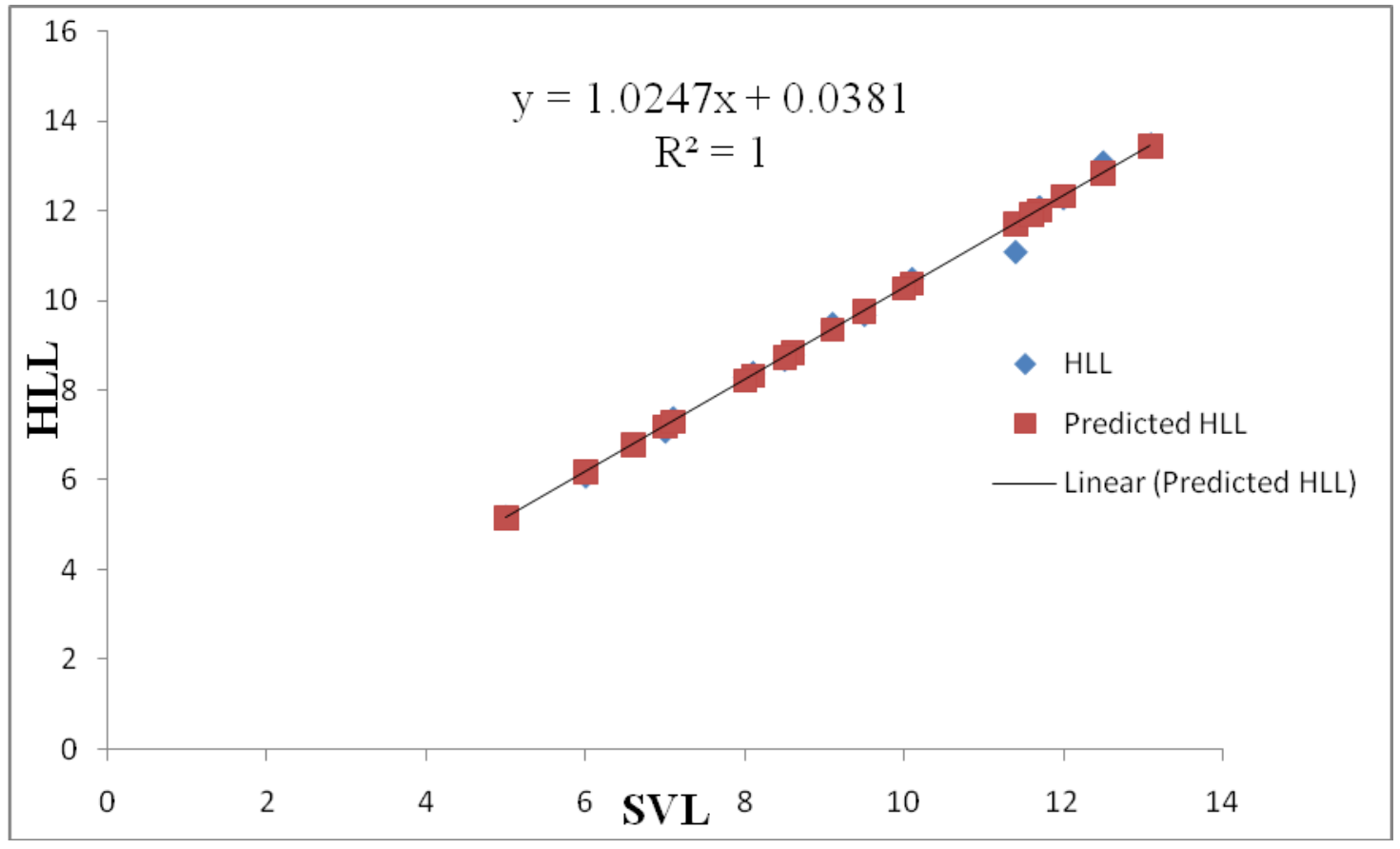

Fig.4b

First finger equals or slightly longer varies in some specimens. Along the dorsal side two series of warts (black cornified) from middle of paratoid glands up to ventis present in adults. Data obtained on the morphometry of the species during the present study would contribute to the knowledge of the bio-ecological perspectives of the species.

Besides many anthropogenic pressures especially road kill is found to be main factor of their decline in current study area. Duttaphrynus melanostictus was the most affected (98\%), species followed by Rana tigrina as reported from the Anamalai Hills (Kumar et al., 2001). The reason behind this massacre is their foraging nature of these toads, which are very fond of gathering around road sides during monsoon for breeding and feeding purposes. Daniels (2005) also reported about their foraging nature, gatheringnear street lamps and vehicle head lights to feast on insects; coupled with their highly eurytopic and human commensally traits (Daniel, 2002; Daniels, 2005) could also be the possible reasons for their higher susceptibility of becoming road kill victims. At last we suggest road barriers and fencing around the sides of roads to stop approaching of amphibians on roads to reduce vehiclecaused mortalities.

\section{References}

Chandra, K., Gajbe, U. 2005. An inventory of herpetofauna of Madhya Pradesh and Chhattisgarh. Zoos' prints J., 20(30): 1812-1819.

Chowdhary, A.K., Bahuguna, V., Bahuguna, S.N. 2014. Morphometric studies on Sphaerotheca breviceps (Schneider, 1799) from Western Himalaya, Srinagar Garhwal region of Uttarakhand. Int. J. Adv. Res., 2(5): 
165-172.

Daniel, J.C. 2002. The Book of Indian Reptiles and Amphibians. Hardcover., Oxford University Press (BNHS), India, 177pp.

Daniels, R.J.R. 2005. Amphibians of Peninsular India. Hyderabad University Press, India, 268pp.

Dinesh, K.P., Radhakrishnan, C., Gururaja, V. K., Deuti, K., and Bhatta, G. 2013.
A Checklist of Amphibian of India. Duellman, W.E., Trueb, L. 1986. Biology of Amphibians. Johns Hopkins University Press, Baltimore, MD.

Kumar, V.S.P., Vasudevan, K., and Ishwar, N.M. 2001. Hepetofaunal mortality on the roads in the Anamalai Hills, Southern Western Ghats. Hamadryad, 26(2): 265-272.

\section{How to cite this article:}

Amit Kotwal, Rajni Raina and Ashwani Wanganeo. 2016. Morphometric Studies on Duttaphrynus melanostictus (Schneider, 1799) Anura: Bufonidae from Central India, Bhopal (MP) with Special Reference to their Mortality by Roads. Int.J.Curr.Microbiol.App.Sci. 5(8): 114-120. doi: http://dx.doi.org/10.20546/ijcmas.2016.508.013 